\title{
A POPULATION AND HARVEST INTENSITY ESTIMATE FOR SOOTY SHEARWATER, PUFFINUS GRISEUS, ON TAUKIHEPA (BIG SOUTH CAPE), NEW ZEALAND
}

\author{
by Jamie Newman, Darren Scott, Henrik Moller and David Fletcher
}

(with one text-figure and two tables)

\begin{abstract}
Newman, J., Scott, D., Moller, H. \& Fletcher, D. 2008(31:x): A population and harvest intensity estimate for Sooty Shearwater, Puffinus griseus, on Taukihepa (Big South Cape), New Zealand. Papers and Proceedings of the Royal Society of Tasmania 142(1): 177-184. https://doi.org/10.26749/rstpp.142.1.177 ISSN 0080-4703. Centre for the Study of Agriculture, Food and Environment, University of Otago, PO Box 56, Dunedin 9054, New Zealand (JN, HM*), 30 Hill Road, Purakanui, Dunedin (DS), Department of Mathematics and Statistics, University of Otago, PO Box 56, Dunedin 9054, New Zealand (DF). *Author for correspondence. Email: henrik.moller@otago.ac.nz

We estimated the total number of burrow entrances, chicks and total population size of the Sooty Shearwater, Puffinus griseus, colony on Taukihepa (Big South Cape), the largest of the 36 Titi Islands where Titi (Sooty Shearwater chicks) are harvested. Between 1999 and 2005 we surveyed six manu (family birded areas) as well as a colony in the interior forested region on the island, measuring entrance density and burrow occupancy and habitat variables, as well as recording birders' harvest intensity. We found little support for any relationship between habitat variables and entrance density on the surveyed manu. Therefore we used a detailed aerial image to map areas and extrapolate these estimates to island totals and a simple population model, incorporating known demographic parameters to calculate the total population size. We estimated that the island contains 1.67 million (95\% CI: $1.47-1.88)$ burrow entrances and 1.12 million (0.959-1.28) breeding pairs, equating to a total of 5.31 million (95\% CI: 3.98-6.77) juveniles, pre-breeders and adults associated with the island. Assuming the harvest intensity on the surveyed manu $0.18 \%(0.16-0.21)$ was similar elsewhere on the unsurveyed but harvested region of the island, we estimated that of the 807000 (712000-901 000) fledging chicks on the island, 137000 (105000-173 000$)$ are harvested each year. These findings highlight the importance of the island both in terms of total Sooty Shearwater population in New Zealand and to the Rakiura Maori who harvest the Titi.
\end{abstract}

Key Words: Puffinus griseus, Sooty Shearwater, Titi, Taukihepa, Big South Cape, New Zealand.

\section{INTRODUCTION}

Taukihepa(Big South Cape Island; 790 ha, $47^{\circ} 14^{\prime} \mathrm{S}, 167^{\circ} 25^{\prime} \mathrm{E}$; fig. 1) is the largest of the 36 Tìtī Islands that surround Rakiura (Stewart Island) in southern New Zealand. In terms of total vegetated area, it represents $54 \%$ of all the Tìtī Islands (based on two-dimensional planar area calculations) and is known to contain one of New Zealand's largest populations of Sooty Shearwater Puffinus griseus (J.F. Gmelin, 1789) (also known as Muttonbird, the chicks commonly referred to as Tìtî). Tìtì on this group of islands, including Taukihepa, are exclusively harvested by Rakiura Māori, New Zealand's southernmost Māori community, as one of the few large-scale customary harvests remaining in New Zealand today (Wilson 1979, Taiepa et al.1997). The sustainability of this harvest is the subject of a long-term research partnership between Rakiura Máori and the Department of Zoology at the University of Otago (Moller et al. 1999). A key component of the Kia Mau Te Tìti Mo Ake Tönu Atu ("Keep the Tìti forever") program is the assessment and ongoing monitoring of Sooty Shearwater populations, both in areas with and without harvesting in order to detect spatial and temporal trends in abundance.

In addition to being of great significance to the Tìti harvesting community, Taukihepa has great conservation potential as an offshore island refuge. Taukihepa became internationally infamous in conservation circles in the 1960s for an ecologically devastating invasion of Black Rat, Rattus rattus (Linnaeus, 1758), that resulted in at least three species extinctions and severely depleted the populations of many of those species that remained. This devastation is one of the most recent and salient examples of the rapid damage an introduced mammal can inflict on a naïve flora and fauna - although the total effect was poorly monitored and documented. Despite the publicity surrounding the rat invasion and the apparent importance of the island, relatively little has been published about the island's flora (Fineran 1973) and fauna, including any information on the abundance of Sooty Shearwater. Burrowing seabirds are recognised as "keystone" species on many offshore islands (Maesako 1999, Sanchez-Pinero \& Polis 2000). They are known to massively elevate the input of nutrients from the marine environment (Hawke \& Newman 2004), as well as increasing levels of biopedturbation (McKechnie 2006), influencing a wide range of ecosystem processes (Fukami et al. 2006). As large sections of Taukihepa have now been extensively surveyed as part of our research program, we are able to report for the first time a Sooty Shearwater population estimate for the entire island based on robust survey techniques.

We also researched the relationship berween burrow entrance density and vegetation to see whether information on habitat could improve the overall estimation of population density both on Taukihepa and elsewhere.

This paper presents data on the size of the colony and the density of the breeding burrows and occupants - leading to an overall estimate of the total number of burrow entrances and Sooty Shearwater chicks on Taukihepa. It describes the relationship between entrance and chick density and habitat variables, and provides an estimate of the number of chicks harvested each year from the island. It also provides an overall estimate of the total population of Sooty Shearwater on Taukihepa, by extrapolating from our total chick estimate using available information on relevant population demographic parameters. In addition, it provides a population baseline just prior to the recent eradication of $R$. rattus from the island (Coote \& Blackwell 2006). 


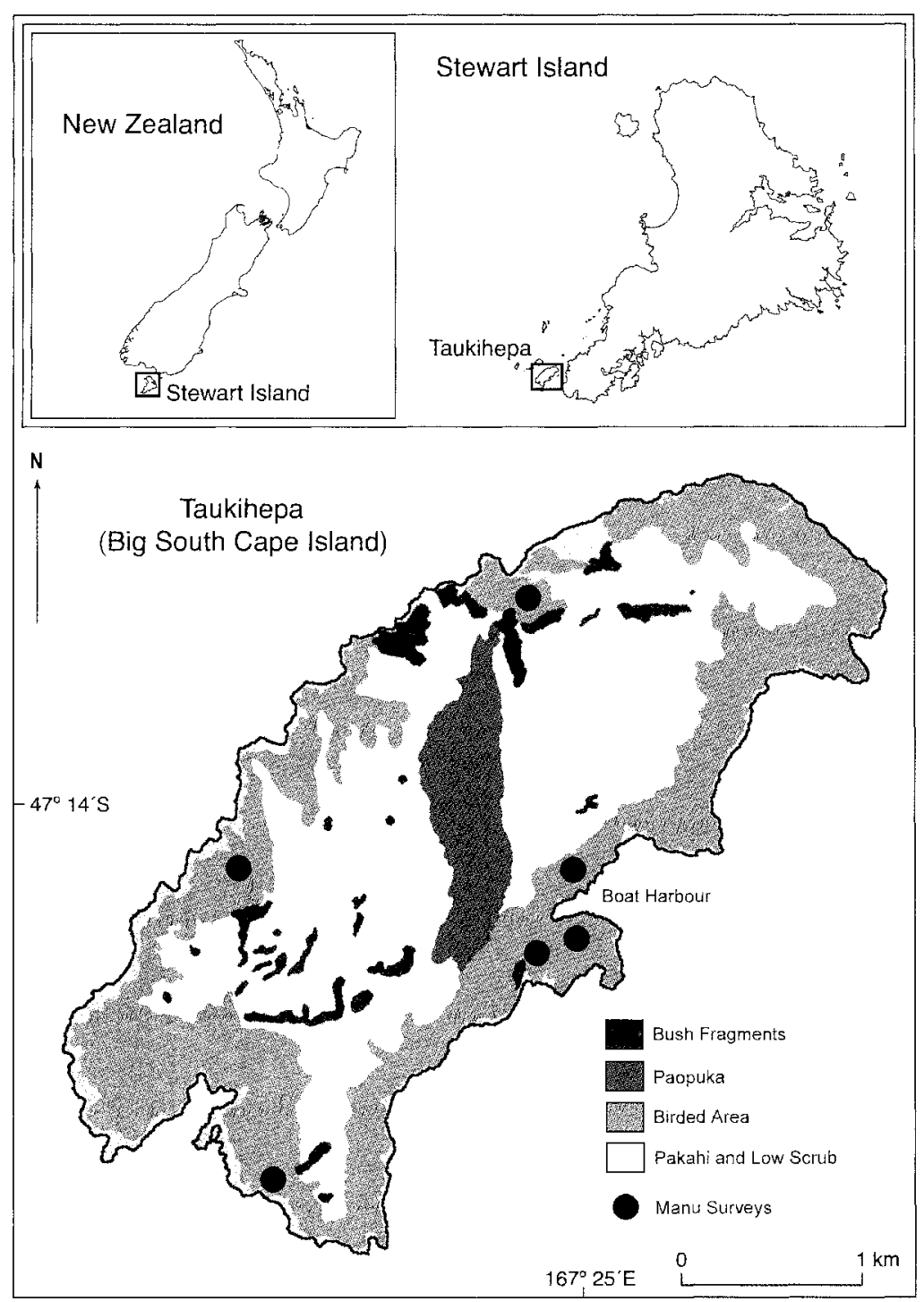

FIG. 1 - Map of Taukihepa showing the vegetation types used in this study and the approximate location of the six manu surveyed.

\section{METHODS}

\section{Sampling design}

As part of the Kia Mau Te Tìtì Mo Ake Tönu Atu Research Project six manu (spatially distinct family birding areas) were comprehensively surveyed to estimate burrow entrance and chick density between 1999 and 2005 (Newman et al. 2008). All of these surveys were carried out between 15 March and 4 April, and always took place prior to any harvesting occurring on the manu.

Each individual manu survey was carried out using a stratified-random sampling design following the same standardised protocol. Typically the manu was split into 8-12 sections based within which 12-24 circular plots and one or two permanent transects were randomly located. The location of section boundaries and transect locations were recorded using handheld 12-channel GPS units (Garmin GPS12). Two-dimensional (surface) areas were calculated from these points using GIS software (MapInfo Professional v6.0) and aerial survey photographs taken in 1976 (Series: $\mathrm{K} / 18 \mathrm{SN} 5003$ ) and 1988 (Department of Conservation 1:4, $\mathrm{f}=50 \mathrm{~mm}$, flight elevation $10000 \mathrm{feet}$ ). Each manu survey typically took four people abour 6-8 days to complete.

\section{Measuring burrow entrance density}

For each circular plot a limited set of habitat variables (table 1) was recorded and the number of burrow entrances within a $3 \mathrm{~m}$ radius plot recorded. In total 1041 circular plots were measured on the six manu surveyed.

\section{Measuring burrow occupancy}

Transects were extended from their random start point on a random bearing until 20 burrow entrances were detected within a $1 \mathrm{~m}$-wide strip ( $2 \mathrm{~m}$ wide in areas of low burrow entrance density) either side of the centre line. Each of the 20 burrow entrances were then prospected using an infra-red burrowscope (Lyver et al. 1998) to determine occupancy. In addition to recording burrow occupancy, a number of detailed habitat and environmental variables was scored along the length of the transects. A subset of these was used for this analysis (table 1). In total 77 transects were established in the six manu surveyed on Taukihepa. 
TABLE 1

Summary of variables measured within circular plots and transects

\begin{tabular}{|c|c|c|}
\hline Variable & Description & $\begin{array}{l}\text { Mean }( \pm S E) \\
\text { Median (range) }\end{array}$ \\
\hline \multicolumn{3}{|c|}{ Circular Plots $(n=1041)$} \\
\hline$\%$ Ground Cover & $\begin{array}{l}\text { Proportion of the plot covered in low level foliage } \\
\text { (up to waist height) }\end{array}$ & $36.1( \pm 1.1), 20( \pm 100)$ \\
\hline \% Canopy Cover & $\begin{array}{l}\text { Proportion of plot covered with some type of canopy } \\
\text { above waist height }\end{array}$ & $78.4( \pm 0.8), 90( \pm 100)$ \\
\hline \multicolumn{3}{|l|}{ Composition of canopy } \\
\hline$\%$ Tüpare & Olearia colensoi & $68.0( \pm 1.0), 80( \pm 100)$ \\
\hline$\%$ Inaka & Dracopbyllum longifolium & $1.4( \pm 0.2), 0( \pm 80)$ \\
\hline$\%$ Hebe & Hebe elliptica & $2.3( \pm 0.3), 0( \pm 90)$ \\
\hline \% Tètēaweka & Olearia oporina & $2.0( \pm 0.3), 0( \pm 100)$ \\
\hline$\%$ Senecio reinoldii & Senecio reinoldii & $0.3( \pm 0.1), 0( \pm 60)$ \\
\hline \% Rātā & Metrosideros umbellata & $0.8( \pm 0.2), 0( \pm 70)$ \\
\hline$\%$ Coprosma spp. & & $0.2( \pm 0.1), 0( \pm 60)$ \\
\hline \% Pseudopanx spp. & & $0.3( \pm 0.1), 0( \pm 80)$ \\
\hline$\%$ Myrsine chathamica & & $0.1( \pm 0.0), 0( \pm 25)$ \\
\hline$\%$ Punga & Tree fern species & $0.4( \pm 0.1), 0( \pm 100)$ \\
\hline$\%$ other & Other species in the canopy & $1.6( \pm 0.3), 0( \pm 95)$ \\
\hline$\%$ sky & & $21.5( \pm 0.8), 10( \pm 100)$ \\
\hline \multicolumn{3}{|l|}{ Transects $(n=77)$} \\
\hline$\%$ Ground Cover & $\begin{array}{l}\text { Proportion of the transect covered in dense foliage } \\
\text { (up to waist height) }\end{array}$ & $34.4( \pm 4.3), 22.5( \pm 100)$ \\
\hline$\%$ Canopy Cover & $\begin{array}{l}\text { Proportion of transect covered with some type of } \\
\text { vegetation }\end{array}$ & $71.4( \pm 3.5), 80( \pm 100)$ \\
\hline Slope & Slope of transect & $15( \pm 1), 15( \pm 39)$ \\
\hline Aspect & Aspect of transect & $191( \pm 13), 200( \pm 358)$ \\
\hline Distance to coast & Distance from transect to nearest point on the coast & $94( \pm 8), 91( \pm 364)$ \\
\hline Elevation & Elevation of the transect & $46( \pm 3), 43( \pm 81)$ \\
\hline
\end{tabular}

\section{Correction factors}

The terrain on Taukihepa is variable and often steep, despite the island's high point being only $230 \mathrm{~m}$ above sea level. We calculated from our measure of slope on each transect that in some cases this could lead to the underestimation of the actual surface of the island by as much as $15 \%$. We therefore estimated the three-dimensional surface area of each manu by adjusting the two-dimensional areas with the average slope recorded over all transects placed within the manu.

Determining burrow occupancy using a burrowscope is known to underestimate the true number of chicks present according to a decreasing function between probability of detection of the burrow occupant and its distance from the burrow entrance. We therefore adjusted the observed occupancy measures on each manu according to the detection correction function provided by McKechnie et al. (2007).

\section{Manu-wide estimates of chick numbers}

The manu-wide estimates of entrance density $(E)$ and chick density $(C)$ were calculated as weighted means over all sections, the weights being proportional to the areas of each section.

\section{Harvest estimates}

Researchers were provided with the total number of chicks harvested from each manu in the year of our field survey there to allow estimation of harvest intensity (proportion of chicks harvested; $\mathrm{H}$ ). The surveys of these six individual manu were permitted by the families who bird thern under the proviso that the resulting information was kept anonymous. A condition of the University of Otago ethics permit given for this research is that the material is reported anonymously. Each family was supplied with a confidential report detailing our findings and copies of each report are also stored at the Department of Zoology, University of Otago. This paper draws together summary information from these reports but cannot list the individual manu involved or any of their detailed results.

If we assume the same harvest intensity for the surveyed and unsurveyed areas, we can estimate the total number of chicks harvested as:

$$
H=\frac{H_{S}}{C_{S}} C_{U}+H_{S}=H_{S}\left(\frac{C_{V}}{C_{S}}+1\right)
$$

where $C_{s}$ and $C_{u}$ are the estimates of the total number of chicks on the surveyed and unsurveyed areas respectively, and $H_{s}$ is the total number of chicks harvested on the surveyed areas. 


\section{Overall island population estimates}

\section{Vegetation classification}

For the purposes of this analysis we classed the vegetation into three distinctive vegetation types recognised by Fineran (1973); (i) Cushion Bog (or Pakahi) and low scrub; (ii) Broadleaf Podocarp forest; and (iii) Tüpare (Olearia colensoi Hook.f., also known as "Muttonbird scrub") dominated coastal forest. The island is almost completely ringed by a dense canopy of Tüpare where all manu are located and where the bulk of the Sooty Shearwater burrows on the island occur - we classified this entire vegetation type as "birded area". The other canopy species occasionally associated with this vegetation type are listed in table 1 . The understory in the birded areas varied from completely open $(0 \%$ ground cover) to completely closed (100\% ground cover). A very sharp fringe zone into the Pakahi typically defines the boundary of this forest type. The Pakahi is a boggy peat habitat typically containing stunted scrub dominated by Dracophyllum longifolium R.Br.; Inaka, Leptospermum scoparium J.R. et G.Forst.; Mānuka, and Metrosideros umbellata Cav.; Rātā, (Fineran 1973). No burrows were ever recorded in this boggy waterlogged habitat. The third main vegetation type, the large Broadleaf/Podocarp forest is almost entirely restricted to one location in the northern lee of a large ridge that crosses the island (fig.1). This entire forest is locally referred to as "Paopuka" and was subject to a full survey in 2005 following the same procedures as described above for the manu surveys.

A number of other small pockets of Broadleaf/Podocarp forests are also scattered around the interior of the island. We termed these areas "bush fragments". Some information on entrance density in these areas was available from visiting a number of them over the years of surveying.

\section{Mapping}

We used a combination of two aerial photographic images taken from surveys flown in 1977 and 1988, ground-truthed with GPS positions, plus our experience on the ground to classify each vegetated area of the island into one of the three main types (fig. 1). When classifying these areas we excluded coastal regions of exposed bare rock. Where the vegetation canopy itself appeared to mark the coastline on our aerial images we set the boundary approximately $5 \mathrm{~m}$ in from the discernable edge in order to allow for overhangs and cliff edges.

\section{Relating vegetation and habitat variables to entrance and chick density}

We sought to increase the power of our overall estimates of chick density by building separate models to link vegetation descriptors to entrance density estimates for circular plots and for transects. A Principal Components Analysis (PCA) was performed using the habitat variables measured in each circular plot (table 1) on all six manu ( $\mathrm{n}=1041)$. Individual scores from the first two PCA axes were then used as predictors of entrance density in a multiple regression. Stepwise regressions using backwards elimination ( $\alpha=0.1$ ) were performed using entrance and chick density estimates as response variables, and slope, elevation, distance from coast, aspect, \%ground cover and \%canopy as predictors on all transects $(n=77)$. All analyses were performed in Minitab (v14.1).

\section{Estimating total number of chicks}

Each coastal section of unsurveyed birded area was flanked by two surveyed manu. We therefore estimated the entrance and chick density in each unsurveyed birded area using the weighted mean and standard error of the corresponding estimates from the two neighbouring surveyed manu, where the weights were proportional to the area of these two manu.

The number of entrances located in the "bush fragments" was estimated from 52 circular plots randomly placed within six of these fragments in 2004 and 2005. The overall estimate of occupancy from the Paopuka was used to estimate the number of chicks in these areas.

\section{Estimating total number of pre-breeders and adults}

Our estimate of the total number of chicks present on Taukihepa before any harvesting took place was used to estimate the total number of juveniles, pre-breeders and adults associated with the island, using the following steps:

1. We constructed an age-based population model. The model involved a post-breeding census and contained 21 age-classes. The last age-class contained those individuals that were at least 20 years old. The details of this are given below with details of the other parameters used in the model.

2. We used the model to estimate the stable age distribution for the population.

3. We used the stable age distribution as an estimate of the current age distribution, and therefore the proportion of the population that were chicks.

4. We divided our estimate of the number of chicks by the estimate of the proportion of the population that were chicks to obtain an estimate of the total population size. Using analogous calculations, we estimated the number of breeders, non-breeders, pre-breeders and juveniles.

The parameters in the population model were specified as follows:

(a) Except for the first two years of life, the annual survival rate was assumed to be the same for all age-classes, and was set at $0.952(95 \% \mathrm{CI}=0.896-0.979$; Clucas et al. in press).

(b) The annual survival rate in the first two years of life was set to the value that led to the population growth rate predicted by the model, matching the observed trajectory of the population over the 14 years of our study (Peery et al. 2006), as measured by changes in burrow entrance density on the nearby island of Putauhinu, an intensely monitored harvested island (Newman et al. 2008). The resulting estimate was $0.525(95 \% \mathrm{CI}=0.203$ to 0.828$)$.

(c) The annual fertility rate for each age-class was set at

$$
f_{i}=\frac{s_{i-1} a_{i} p b}{2}
$$

where $s_{i-1}$ is the annual survival rate for individuals in age-class $i-1, a_{i}$ is the proportion of individuals in age-class $i$ that are adult, $p$ is the proportion of adults that are breeding (assumed to be the same for all age-classes), and $b$ is the proportion of eggs laid that develop into a fledged chick (also assumed to be the same for all age-classes).

(d) An estimate of the proportion of individuals in ageclass $i$ that are adult was obtained in two steps. We first obtained an estimate of the proportion in each age-class that would be at the colony using a method proposed by Spendelow et al. (2002). This involved fitting an age-specific model for "probability of first-return" to mark-recapture data obtained from banding chicks at The Snares and Taiaroa 
Head. We then combined this model with an estimate of the delay between arrival at the colony and first breeding attempt using data from a long-term study of Short-tailed Shearwater, Puffinus tenuirostris (Teminck, 1835), on Fisher Island to obtain an estimate of the proportion of individuals in each age-class that are adult. These final estimates led to an estimate of the mean age at first reproduction of 7.9 years (D. Fletcher et al., unpubl. data).

(e) An estimate of the proportion of adults that are breeding in any one season was obtained using additional data from the study of Short-tailed Shearwater referred to above. Over a period of 41 years (1952-92), the average proportion of adults observed to be breeding was 0.722 $(\mathrm{SE}=0.018)$ (S. Bradley, unpubl. data).

(f) An estimate of the proportion of eggs laid that develop into a fledged chick was obtained by calculating a weighted mean of the estimates for The Snares and Whenua Hou (Newman et al. in press). The resulting estimate was 0.722 $(95 \% \mathrm{CI}=0.652$ to 0.783$)$.

(g) Confidence intervals for the harvest, number of breeding pairs, adults and total population estimates were obtained by Monte Carlo simulation, with each model parameter being resampled 1000 times from its estimated sampling distribution (Davison \& Hinkley 1997).

\section{RESULTS}

\section{Vegetation on the island}

The area of Taukihepa estimated to be covered in vegetation was 797 ha, of which 302 ha $(38 \%)$ could be classed as birded area and $414 \mathrm{ha}(52 \%)$ as Pakahi, where no burrows were found. The Paopuka forest occupied a further 61.6 ha $(8 \%)$ of the island, while bush fragments comprised less than 19.0 ha $(2 \%)$ (table 2 ). In total our detailed surveys of the six individual manu covered 63.5 ha or $21 \%$ of the total estimated birded area available on the island (table 2, fig. 1).

No individual PCA axis could explain much variability in the circular plot vegetation data. The first axis accounted for less than $16 \%$ and the second for only $10 \%$ of the variability. Multiple regression of these two scores against entrance density also resulted in a poor fit, explaining less than $1 \%$ (R-Squared) of the observed variability in entrance density. This suggests at best a very weak (or even no) relationship between the manu vegetation and circular plot entrance density on the manu.

Stepwise regressions revealed few relationships between transect habitat variables and entrance or chick density. The global model containing all predictors of entrance density explained only $14 \%$ of the variation. The best fitting model predicting chick density was an even poorer fit, explaining only $5 \%$ of the variability.

As we were unable to adequately describe more than $15 \%$ of the variation in entrance or chick density using any of the habitat variables measured we discarded all attempts to estimate Tìt $\overline{1}$ density on unsurveyed birded areas based on habitat variables.

\section{Harvest Intensity}

The harvest intensity on the surveyed areas was estimated to be 0.18 (95\% CI: $0.16-0.21$ ). Use of Equation 1 gives a total estimate of 137000 chicks (95\% CI: $105000-173$ 000 ) being harvested each year from Taukihepa.

\section{Overall Population estimates}

We estimated that the island contained 1.67 million $(95 \%$ CI: $1.47-1.88$ ) entrances containing 807000 (95\% CI: $712,000-901000)$ chicks prior to harvesting on average over the six years of study. This translates to 1.12 million (95\% CI: 0.959-1.28) breeding pairs (at the point of egg laying). We estimate that there are 3.24 million (95\% CI: 2.93-3.57) adults and 5.31 million (95\% CI: 3.98-6.77) Sooty Shearwaters in total associated with Taukihepa just prior to the breeding season.

\section{DISCUSSION}

\section{Habitat area}

The total area of the vegetated portion of Taukihepa we report here (797 ha) is considerably smaller than any previously published estimate of the island's size ( 930 ha; Fineran 1973). This discrepancy (of around $15 \%$ ) is likely to be due to a combination of our exclusion of any bare rock and coastal fringes and/or the rounding up of less detailed historical estimates of the islands size based on cruder mapping. We

TABLE 2

Estimated area, number of entrances and chicks on Taukihepa

\begin{tabular}{lcrr}
\hline Section of Island & Area (ha) & Entrances $( \pm$ SE) & \multicolumn{1}{c}{ Chicks $( \pm$ SE $)$} \\
\hline Manu: surveyed & 63.5 & $320000( \pm 69,700)$ & $161000( \pm 80,800)$ \\
Birded area: unsurveyed & 238 & $979000( \pm 68,900)$ & $587000( \pm 94,000)$ \\
Total birded area & 302 & $1300000( \pm 98,000)$ & $748000( \pm 117,000)$ \\
Paopuka & 61.6 & $345000( \pm 28,000)$ & $55600( \pm 16,000)$ \\
Bush fragments & 19.0 & $28000( \pm 15,800)$ & $3073( \pm 3,490)$ \\
All colonies combined & & $1670000( \pm 103,000)$ & $807000( \pm 118000)$ \\
Pakahi & 415 & & \\
Total vegetated area & 797 & & \\
Toral land area & 930 & & \\
\hline
\end{tabular}

${ }^{1}$ From Fineran (1973) 
consider our estimate of the vegetated portion of the island containing Sooty Shearwater colonies to be the most robust currently available, as it is based upon extensive ground-based surveying, GPS fixes and detailed aerial images.

The classification of the vegetated portion of the island into the three main vegetation types was a relatively simple procedure, primarily due to the sharply defined and easily discernable boundaries that typically exist between the vegetation types. The results from this classification reinforce the importance of Sooty Shearwaters to this island's ecosystem - with Sooty Shearwater colonies occupying $48.0 \%$ of the vegetated area of the island.

\section{Lack of habitat predictors of burrow density}

Our attempts to explain variation in Sooty Shearwater burrow entrance and chick density within the birded area vegetation using any of the habitat variables were largely unsuccessful. This allowed us to adopt a simple approach ignoring habitat when estimating the number of entrances in the remaining unsurveyed birded area. Previous attempts to relate habitat variables to Sooty Shearwater entrance density on other islands have shown mixed results. Some studies have reported differences in entrance densities between broad vegetation types (Charleton 2002, Scott et al. 2008, unpubl. data). For example, Charleton (2002) reported that $34.4 \%$ of the variation in entrance density on Whenua Hou (Codfish Island) could be explained by habitat and location variables on the eastern side of the island. However, a more recent study of this entire island by Scott et al. (2005, unpubl. data) found that only $25.6 \%$ of the variation in entrance density could be explained by vegetation and location descriptors when sampling was confined within known colonies. Distance from coast (negative), elevation (positive), canopy height (negative), and the elevation*aspect interaction were found to be weak but significant predictors of entrance density. We also found very weak support for distance from coast and elevation as predictors, but none for aspect, so our results are only partially consistent with earlier studies. ReyesArriagada et al. (2007) investigated habitat predictors of Sooty Shearwater entrance density on Guafo, an island in Chile. They found no relationship with slope (although they claim the birds preferred steeper slopes between 19-37 degrees), but reported that birds preferred north- and west-facing aspects. We suggest this may have been an artifact of their study design as only a small portion of the northwest region of the island was sampled. In contrast, we found no relationship between entrance density and slope. Furthermore, entrances were found over a wider range of slopes (table 1).

The apparent differences between these studies may result from the islands being so different in size, location, flora and fauna (including introduced species), geology and anthropogenic histories. All of these factors could conceivably mask or confound any common pattern. Nevertheless within the birded area of Taukihepa, entrance density was found to be relatively uniform $(0.44 \pm 0.11$ entrances $\mathrm{m}^{2}$ ), giving us confidence in our approach.

\section{Harvest Intensity}

Harvest intensity was found to be highly variable on the six manu surveyed on Taukihepa (range 5.00-31.0\%). These surveyed manu were not selected randomly because we were able to sample only where birding families welcomed the research. Therefore our extrapolation of the average harvest intensity from these manu to estimate the number harvested on the unsurveyed regions is made with caution.

No relationship between harvest intensity and chick density has been described (Newman et al. 2008). Traditional Ecological Knowledge and management by the birders includes manipulation of burrow length and vegetation in ways that are aimed at increasing burrow density (Kitson \& Moller 2008, Moller \& Lyver in press), in which case burrow entrance density may become higher on birded ground. On the other hand if harvesting decreases overall population abundance, unharvested refuge areas within the birded area may come to have higher abundance than we measured on birded manu.

The only other published record of Sooty Shearwater harvest intensity comes from the adjacent Poutama Island. Lyver (2000) reported harvest intensities of 16.9\% (95\% CI: $12.6-24.4)$ and $22.6 \%$ (95\% CI: 18.4-28.3) on this smaller island ( $-60 \mathrm{ha})$ in 1994 and 1995 respectively comparable intensities to those reported here.

\section{Reliability of Taukihepa population estimate}

Our surveys on Taukihepa were carried out over six years. Breeding burrow entrance density was very stable from one year to the next (Newman et al. 2008), whereas burrow occupancy varied greatly between years according to wide variation in breeding success (Wooller et al. 1990, Newman et al. in press). It is therefore most appropriate to combine our estimates from single years into a single overall Taukihepa population estimate. There is tentative evidence that more crowded colonies have lowered breeding success (Newman et al. 2008, Newman et al. in press), so we used a combined estimate from The Snares (high density) and Whenua Hou (low density) to extrapolate to Taukihepa. Breeding burrow density is near the middle range on Taukihepa (Newman et al. 2008) so our extrapolation from the median is the most appropriate. Repeated monitoring of transects at nearby Putauhinu Island and Whenua Hou island (fig. 1) showed that the Tîti population was approximately stationary over the period of our study (Newman et al. 2008). Therefore combining surveys between years is likely to give a robust estimate of the number of breeding attempts (eggs laid). Overall, then, our field sampling and bootstrapping approach will have provided robust estimates of average chick numbers and harvest intensity, and a measure of the uncertainty around those estimates.

Assessing the reliability of the overall Sooty Shearwater population estimate is more problematic because it relies on a population model to estimate the population's age structure. Use of breeder "skipping rate" from Short-tailed Shearwaters is unlikely to have introduced much error because elasticity analyses show that this parameter has relatively little impact on population outcomes (Hunter $\mathrm{et} \mathrm{al}$. 2000). The key determinant of population growth rate and population structure is the adult survival rate, a parameter that we have been able to estimate accurately by allowing for pre-breeder emigration rates (Clucas et al. 2008).

\section{Future population monitoring and trends}

The Sooty Shearwater population on Taukihepa may now increase following recent eradication of Black Rats and reduction in Weka, Gallirallus australis (Sparrman, 1786), abundance on Taukihepa (Coote \& Blackwell 2006, Dillingham et al. 2007). Potential changes resulting from 
increased fledging rates of Tìti must be placed within the wider context of other factors that potentially influence Sooty Shearwater populations, including future changes in oceanic productivity, climate change, fisheries bycatch and harvest pressure. Better understanding of density-dependent processes acting within Sooty Shearwater populations is also needed before the future trajectory of the population can be predicted (Newman et al. 2008). This study provides a firm baseline for future study of the collective impact of these factors.

\section{Other petrel species on the island}

The only other seabird known to breed on Taukihepa in large numbers is the Korure or Mottled Petrel, Pterodroma inexpectata (J.R. Forster, 1844). Its breeding burrows are interspersed with Sooty Shearwater burrows on the steep northeastern face within the Paopuka forest (Scott et al. 2005) and the lower gullies around Boat Harbour (S. Bull, pers. comm.). Burrowscoping of all transects on the six manu surveyed did not reveal any Mottled Petrels, so we have assumed that they are not present in the Tüpare classified vegetation type. Our 2005 survey of Paopuka differentiated between Mottled Petrel and Sooty Shearwater burrows and estimated that there were around $21000( \pm 9310,95 \%$ confidence interval) Mottled Petrel chicks in the Paopuka area alone (Scott et al. 2005).

\section{The importance of seabirds and birding}

Burrowing seabirds such as Sooty Shearwater are known to be important components of island ecosystems, often being described as ecosystem "drivers" or "engineers". Although the true extent of their role and influence is only now starting to be understood (Harding et al. 2004, Hawke \& Holdaway 2005, Hawke \& Newman 2005, Bancroft et al. 2005, 2008, Fukami et al. 2006, McKechnie 2006), clearly the contributions seabirds can make to island ecosystems are considerable. Our estimate of over five million Sooty Shearwaters associated with an island of only 930 ha in size is astounding and provides some insight into the scale of the island-seabird interactions and processes operating there.

Taukihepa represents $58 \%$ of the total vegetated area on all Tĩtī Islands (Newman et al. 2008). The entrance and chick densities as well as harvest intensity reported here are therefore likely to be roughly indicative of the national averages on the remainder of the Tìtī Islands. If so, an overall national annual harvest of Sooty Shearwater chicks will have been approximately 300000 chicks on average during our study (1999-2005). This is comparable to the overall take of Short-tailed Shearwater chicks in Tasmania during the 1980s (Skira 1990, 1994), but $70 \%$ higher than the average harvest between 1994 and 1997 (I.J. Skira, in litt. cited in Moller 1998). The Rakiura harvest intensity of around $18 \%$ reported here is half that reported by Skira \& Wapstra (1980) for Tasmanian commercially harvested colonies, and a fifth of that recorded at some recreationally harvested colonies. Unlike the Tasmanian Muttonbird harvest, which has declined over the past century (Skira 1990), the Rakiura harvest grew rapidly after the Second World War and has maintained current levels over the past two decades (Newman et al. 2008). The supreme importance of the harvest for Rakiura Mãori cultural identity, maintenance of knowledge and connection to ancestral lands (Kitson \& Moller 2008) motivated this detailed study of chick numbers, population size and harvest intensity on Taukihepa, the main island where harvests occur. The Kia Mau te Titì Mo Ake Tönu Atu ("Keep the Tìtī Forever") research project will now combine this study with surveys on other islands, analysis of trends in harvest success (Lyver et al. 1999, Newman et al. 2008) and population models incorporating climate change to predict whether the Tìtì will remain plentiful enough for the Rakiura mokopuna (grandchildren) to continue their cultural inheritance and traditional wildlife harvest.

\section{ACKNOWLEDGEMENTS}

We thank the Rakiura Tìtī Islands Administering Body for guidance throughout the study and we are grateful to the muttonbirders on Taukihepa for hospitality and for allowing the research to be undertaken on the island. Hannah Nevins (Oikonos, USA) helped with fieldwork on the Paopuka site. A large number of other people assisted with the large amount of fieldwork summarised in this paper - although too numerous to list here we are grateful to them all for their efforts. Stuart Bradley kindly provided unpublished information on Short-tailed Shearwater breeding frequency from Fisher Island. Financial assistance was provided by the Foundation for Research, Science and Technology, University of Otago, and New Zealand Aluminium Smelters Ltd. Logistical assistance was provided by Southwest Helicopters. Stuart Bradley, Mike Imber, Jessica Lach, Ben Knight and Theresa Downs provided valuable comments on an earlier version of this manuscript.

\section{REFERENCES}

Bancroft, W.J., Roberts, J.D. \& Garkaklis, M.J. 2005: Burrowing seabirds drive decreased diversity and structural complexity, and increased productivity in insular vegetation communities. Australian Journal of Botany 53: 231-241.

Bancroft, W.J., Roberts, J.D. \& Garkaklis, M.J. 2008: Vertebrate fauna associates of the Wedge-tailed Shearwater, Puffinus pacificus, colonies of Rottnest Island: influence of an ecosystem engineer. Papers and Proceedings of the Royal Society of Tastnania 142(1): 21-30:

Charleton, K.J. 2002: Variation in Sooty Shearwater burrow entrance density, burrow use and chick emergence: Science and Traditional Environmental Knowledge approaches. Unpublished MSc thesis, University of Otago, Dunedin.

Clucas, R., Fletcher, D.J. \& Moller, H. 2008: Estimates of adult survival rate for three Sooty Shearwater (Puffinus griseus) colonies in New Zealand. Emu 108: 237-250.

Coote, R. \& Blackwell, G. 2006: Rats removed! Titi Times 18: $2-3$.

Davison, A.C. \& Hinkley, D.V. (1997) Bootstrap Methods and their Application. Cambridge University Press, Cambridge, UK: $582 \mathrm{pp}$.

Dillingham, P., McKechnie, S., Harper, G., Fletcher, D. \& Moller, H. 2007. A model-based assessment of the impact of predator control on populations of Tìtì (Sooty Shearwaters; Puffinus griseus). Report prepared for Ka Mate Ngā Kiore (Kill the Rats) Incorporated Society. University of Otago Wildlife Report No. 206: $30 \mathrm{pp}$.

Fineran, B.A. 1973: A botanical survey of seven mutton-bird islands, south-west Stewart Island. Journal of Royal Society of New Zealand 3: 475-526.

Fukami, T., Wardle, D.A., Bellingham, P.J., Mulder, C.P.H., Towns, D.R., Yeates, G.W., Bonner, K.I., Durrett, M.S., Grant-Hoffman, M.N. \& Williamson, W.M. 
2006: Above- and below-ground impacts of introduced predators in seabird-dominated island ecosystems. Ecology Letters 9: 1299-1307.

Harding, J.S., Hawke, D.J., Holdaway, R.N. \& Winterbourn, M.J. 2004: Incorporation of marine-derived nutrients from petrel breeding colonies into stream food webs. Freshwater Biology 49: 576-586.

Hawke, D.J. \& Holdaway, R.N. 2005: Avian assimilation and dispersal of carbon and nitrogen brought ashore by breeding Westland Petrels (Procellaria westlandica): a stable isotope study. Journal of Zoology 226: 419-426.

Hawke, D.J. \& Newman, J. 2004: Inventories and elemental accumulation in peat soils of forested seabird breeding islands, southern New Zealand. Australian Journal of Soil Research 42: 45-48.

Hawke, D.J. \& Newman, J. 2005: Using isotope analysis to identify incorporation of marine nutrients in terrestrial birds at Snares Islands. Notornis 52: 108-111.

Hunter, C.M., Moller, H. \& Fletcher, D. 2000: Parameter uncertainty and elasticity analyses of a population model: setting research priorities for shearwaters. Ecological Modelling 134: 299-323.

Kitson, J.C. \& Moller, H. 2008: Looking after your ground: resource management practice by Rakiura Māori Tìti harvesters. Papers and Proceedings of the Royal Society of Tasmania 142(1): 161-176.

Lyver, P.O'B. 2000: Sooty Shearwater (Puffinus griseus) harvest intensity and selectivity on Poutama Island, New Zealand. New Zealand Journal of Ecology 24: 169-180.

Lyver, P.O'B., Hamilton, S., McKenzie, M., Dickson, I., Dooher, T., Broad, T. \& Moller, H. 1998: A burrowscope for examining petrel nests in burrows. Conservation Advisory Science Notes 209: $21 \mathrm{pp}$.

Lyver, P., Moller, H. \& Thompson, C. 1999: Changes in Sooty Shearwater (Puffinus griseus) chick production and harvest precede ENSO events. Marine Ecology Progress Series 188: $237-248$

Maesako, Y. 1999: Impacts of Streaked Shearwater (Calonectris leucomelas) on tree seedling regencration in a warmtemperate evergreen forest on Kanmuri-jina Island, Japan. Plant Ecology 145: 183-190.

McKechnie, S. 2006: Biopedturbation by an island ecosystem engineer: burrowing volumes and litter deposition by Sooty Shearwaters (Puffinus griseus). New Zealand Journal of Zoology 33: 259-265.

McKechnie, S., Fletcher, D., Moller, H., Scott, D., Newman, J. \& Bragg, C. 2007: Estimating and correcting for bias in population assessments of Sooty Shearwaters. Journal of Wildlife Management 71: 1325-1335.

Moller, H. 1998: Aussies over here! Titi Times No. 5: 9

Moller, H., de Cruz, J., Fletcher, D., Garrett, K., Hunter, C., Jones, C.J., Kitson, J., Lyver, P., Newman, J., Russell, B., Scofield, P. \& Scott, D. 1999: Kia Mau Te Titi Mo Ake Tonu Atu: Goals, design and methods. University of Otago Wildlife Management Report 117: 76 pp.

Moller, H. \& Lyver, P.O'B. in press: Using Traditional Ecological Knowledge for improved sustainability: case studies from four customary wildlife harvests by Māori in New Zealand.
In Hughes, C. (ed.): Indigenous People and Biodiversity Conservation. Conservation International, Arlington.

Newman, J., Clucas, R., Moller, H., Fletcher, D., Bragg, C., Mckechnie, S. \& Scott, D. 2008: Sustainability of Tìtī harvesting by Rakiura Mäori: A synthesis report. University of Otago Wildlife Report: $210 \mathrm{pp}$.

Newman, J., Fletcher, D., Moller, H., Harper, G., Bragg, C., Scott, D. \& McKechnie, S. in press: Improved estimates of breeding success for a burrow nesting petrel, the Sooty Shearwater (Puffinus griseus), from nine years of monitoring. Wildlife Research.

Peery, M.Z., Becker, B.H. \& Beissinger, S.R. 2006: Combining demographic and count-based approaches to identify source-sink dynamics of a threatened seabird. Ecological Applications 16: 1516-1528.

Reyes-Arriagada, R., Campos-Ellwanger, P., Schlatter, R.P. \& Baduini, C. 2007: Sooty Shearwater (Puffinus griseus) on Guafo Island: the largest seabird colony in the world? Biodiversity and Conservation 16: 913-930.

Sanchez-Pinero, F. \& Polis, G.A. 2000: Bottom-up dynamics of allochthonous input: direct and indirect effects of seabirds on islands. Ecology 81: 496-504.

Scott, D.S., Newman, J., Fletcher, D., McKecknie, G., Moller, H. \& Bragg, C. 2005: A survey of Tìī abundance, Paopuka, Taukihepa. University of Orago Reporr: No. 801-2: 20 pp.

Scott, D., Scofield, P., Hunter, C. \& Fletcher, D. 2008: Decline of Sooty Shearwaters Puffinus griseus on The Snares, New Zealand. Papers and Proceedings of the Royal Society of Tasmania 142(1): 185-196.

Skira, I.J. 1990: Human exploitation of the Short-tailed Shearwater (Puffinus tenuirostris). Papers and Proceedings of the Royal Society of Tasmania 124(1): 77-90.

Skira, I.J. 1994: Tasmanian aborigines and muttonbirding: an historical examination Unpublished $\mathrm{PhD}$ thesis. University of Tasmania: $358 \mathrm{pp}$.

Skira, I.J. \& Wapstra, J.E. 1980: Occupation of burrows as a means of estimating the harvest of Short-tailed Shearwaters in Tasmania. Emu 80: 233-238.

Spendelow, J.A, Nichols, J.D., Hines, J.E., Lebreton, J.D. \& Pradel, R 2002: Modelling post-fledging survival and age-specific breeding probabilities in species with delayed maturity: a case study of Roseate Terns at Falkner Island. Connecticut Journal of Applied Statistics 29: 385-405.

Taiepa, T., Lyver, P., Horsley, P., Davis, J., Bragg, M. \& Moller, H. 1997: Co-management of New Zealand's Conservation Estate by Mãori and Pākehā: a review. Environmental Conservation 24: 236-250.

Wilson, E. 1979: Titi Heritage - The Story of the Muttonbird Islands. Craig Printing, Invercargill: $181 \mathrm{pp}$.

Wooller, R.D., Bradley, J.S., Skira, I.J. \& Serventy, D.L. 1990; Reproductive success of Short-tailed Shearwaters Puffinus tenuirostris in relation to their age and breeding experience. Journal of Animal Ecology 59: 161-170.

(accepted 5 August 2008) 